\title{
Efektivitas Ultrasound The rapy Dan Auto Stretching Dengan Penambahan Neuromuscular Taping Terhadap Penurunan Nyeri Dan Peningkatan Luas Gerak Sendi Proximal Interphalangeal Pada Pasien Trigger Finger Di Rumah Sakit Muhammadiyah Palembang
}

\author{
${ }^{1}$ Juliastuti, ${ }^{1}$ Aisyah Dwi Ayu Alma, ${ }^{1}$ Sarina \\ ${ }^{1}$ Program Studi Diploma III Fisioterapi STIKes Muhammadiyah Palembang. \\ Jalan Jendral Ahmad Yani 13 Ulu Plaju Palembang 30252 \\ 凶email: juliastuti.arlz@gmail.com \\ Tanggal Submisi: 7 Juli 2020; Tanggal Penerimaan: 14 Juli 2020
}

\begin{abstract}
ABSTRAK
Trigger finger adalah kondisi yang menyerang tendon-tendon pada jari atau ibu jari, sehingga membatasi gerakan pada jari. Tujuan penelitian ini untuk mengetahui seberapa signifikan efek penerapan modalitas fisioterapi berupa Ultrasound dan Auto Stretching dengan penambahan Neuromuscular Taping pada pasien trigger finger di Rumah Sakit Muhammadiyah Palembang. Metode penelitian ini menggunakan pendekatan Single-Case dengan desain A-BA dengan ketentuan A1 adalah kondisi baseline awal sebelum diberi perlakuan, B adalah kondisi pemberian treatment, A2 adalah kondisi baseline pengulangan atau follow up setelah pemberian intervensi. Intervensi yang digunakan berupa modalitas Ultrasound therapy dan Auto Stretching dengan penambahan Neuromuscular Taping selama 1 minggu. Populasi penelitian ini adalah pasien poliklinik fisioterapi Rumah Sakit Muhammadiyah Palembang dengan diagnosa Trigger Finger. Pengambilan sampel dilakukan secara matching alocation karena pemilihan sampel dilakukan atas pertimbangan tertentu sesuai dengan kriteria yang ditetapkan berdasarkan variabel yang diteliti. Pada penelitian ini seluruh populasi menjadi sampel. Analisis data dalam penelitian ini menggunakan statistik deskriptif yang sederhana dengan menggunakan grafik garis sebagai suatu gambaran dari pelaksanaan dan hasil eksperimen. Hasil penelitian didapatkan penurunan derajad nyeri gerak dengan Visual Analoque Scale (VAS) terhadap 5 (lima) subjek, pada baseline awal (intervensi Ultrasound therapy) rata-rata nilai VAS 6,46, pada fase treatment (penambahan NMT) rata-rata nilai VAS 5,07 dan pada fase baseline 2 atau fase follow up rata-rata nilai VAS 4,49, terdapat peningkatan LGS proximal interphalangeal, pada baseline awal (intervensi Ultrasound therapy) rata-rata nilai LGS proximal interphalangeal $25^{\circ}$, pada fase treatment (penambahan NMT) rata-rata nilai LGS $29.1^{0}$ dan pada fase baseline 2 atau fase follow up rata-rata nilai LGS $31.9^{\circ}$. Simpulan penelitian ini adanya perubahan nyeri dan lingkup gerak sendi pada baseline 1, treatment, dan baseline 2 .
\end{abstract}

Kata kunci : Trigger Finger, nyeri, Visual Analoge Scale (VAS), Luas Gerak Sendi (LGS), autostretching, ultrasound therapy, Neuromuskular Taping

\section{ABSTRACT}

The trigger finger is the cause that attacks the tendons on the finger or thumb, thereby encouraging movement on the finger. The purpose of this study was to study the significant effect of the application of physiotherapy modalities consisting of Ultrasound and Auto Stretching using Neuromuscular Taping in trigger finger patients at Muhammadiyah Hospital Palembang. This research method uses a Single-case design A-B-A with the provisions that $A 1$ is the initial condition before being given approval, $B$ is a condition for the provision of care, A2 is a basic condition of repetition or follow-up after giving intervention. The interventions used consisted of ultrasound therapy modalities and Auto Stretching using Neuromuscular Taping for 1 week. The study population was physiotherapy 
gerak sendi membantu peningkatan kekuatan, fungsi, dan gaya berjalan (Hayes dan Hall, 2015). Pemberian modalitas NMT dan US pada Kondisi trigger finger juga dapat dikombinasikan dengan pemberian Auto Stretching yaitu pasien melakukan self stretching secara aktif untuk meningkatkan fleksibilitas secara aktif dan menguatkan otot agonis (Dillah \& Imron, 2013).

Penelitian ini bertujuan untuk mengetahui seberapa signifikan efek penerapan modalitas fisioterapi berupa UltraSound Therapy dan Auto Stretching dengan penambahan Neuromuscular Taping pada kondisi Trigger Finger di Rumah Sakit Muhammadiyah Palembang.

\section{METODE PENELITIAN}

Penelitian ini menggunakan jenis penelitian quasi experimental dan menggunakan pendekatan metode penelitian Single-Case Research serta desain yang digunakan adalah desain A-B-A. Dengan ketentuan, A1 adalah kondisi baseline awal sebelum diberi perlakuan, $\mathrm{B}$ adalah kondisi pemberian treatment, A2 adalah kondisi baseline pengulangan atau follow up setelah pemberian intervensi (Horner et al., 2005).

Penelitian ini dibagi menjadi tiga fase, yaitu fase pengamatan pertama baseline 1 (A1), fase kedua yaitu treatment (B), dan yang ketiga fase pengamatan kedua setelah diberi treatment yaitu baseline 2 (A2). Setiap masing-masing fase selesai, pasien dilakukan pengukuran derajad nyeri dengan skala Visual Analoque Scale (VAS) dan pengukuran luas gerak sendi (LGS) proximal interphalangeal dengan goniometer.

\section{Baseline 1 (A1)}

Pada fase ini, pasien hanya menerima treatment fisioterapi berupa Ultrasound therapy dan Auto Stretching.

2. Treatment $(\mathrm{B})$

Pada fase ini pasien diberi intervensi Ultrasound therapy, Auto Stretching dan penambahan Neuromuscular Taping.

\section{Baseline 2 (A2)}

Pada fase ini pasien hanya menerima treatment fisioterapi berupa Ultrasound therapy dan Auto Stretching.

Populasi pada penelitian ini yaitu pasien Poliklinik Fisioterapi Rumah Sakit Muhammadiyah Palembang dengan diagnosa Trigger Finger. Pengambilan sampel dilakukan secara matching alocation karena pemilihan sampel dilakukan atas pertimbangan tertentu sesuai dengan kriteria yang ditetapkan berdasarkan variabel yang diteliti. Pada penelitian ini seluruh populasi menjadi sampel. responden yang menjadi sampel yaitu responden yang telah dilakukan tes spesifik untuk mendeteksi adanya Trigger Finger.

Variabel penelitian ini terdiri dari variable independent yaitu Intervensi Ultrasound therapy, Intervensi Auto Stretching dan Neuromuscular Taping (NMT), sedangkan variable dependent dalam penelitian ini adalah hasil pengukuran derajad nyeri dengan VAS dan pengukuran luas gerak sendi jari-jari dengan Goniometer.

Teknik analisa data dalam penelitian ini menggunakan sumber data primer dengan cara observasi dan pengukuran langsung terhadap subjek. Jenis data dalam penelitian ini adalah data numerik yaitu nilai skala VAS dan hasil pengukuran LGS. Dalam penelitian ini pengolahan data bertujuan untuk mendapatkan suatu informasi data subjek yang nantinya dinilaikan sebagai hasil dari pengukuran nilai nyeri dengan skala VAS dan LGS.

Analisa data merupakan tahap terakhir sebelum penarikan kesimpulan. Dalam penelitian eksperimen dengan single-case research, data di analisa menggunakan statistik deskriptif yang sederhana dengan tujuan memperoleh gambaran secara jelas tentang hasil intervensi dalam jangka waktu tertentu. Dengan menggunakan grafik garis sebagai suatu gambaran dari pelaksanaan dan hasil eksperimen. 


\section{HASIL}

Penelitian ini dilaksanakan pada bulan Agustus 2019 di Poliklinik Fisioterapi Rumah Sakit Muhammadiyah Palembang. Berdasarkan hasil penelitian yang dilaksanakan di bagian Fisioterapi Rumah Sakit Muhammadiyah Palembang, didapatkan 5 (lima) subjek penelitian.

1. Karakteristik Subjek Penelitian

Tabel 1. Karakteristik Subjek Penelitian

\begin{tabular}{ccccc}
\hline Nama & Umur & $\begin{array}{c}\text { Jenis } \\
\text { Kelamin }\end{array}$ & $\begin{array}{c}\text { Lama } \\
\text { Keluhan }\end{array}$ & $\begin{array}{c}\text { Jari } \\
\text { Tangan }\end{array}$ \\
\hline Ny "A" & 63 tahun & Perempuan & 3 bulan & Kanan \\
\hline Ny "Y" & 59 tahun & Perempuan & 2 bulan & Kanan \\
\hline Ny "M" & 64 tahun & Perempuan & 3 bulan & Kanan \\
\hline Ny "N" & 56 tahun & Perempuan & 1 bulan & Kanan \\
\hline $\begin{array}{c}\text { Ny } \\
\text { "YA" }\end{array}$ & 52 tahun & Perempuan & 2 bulan & Kanan \\
\hline
\end{tabular}

2. Hasil pengukuran derajad nyeri gerak dengan Visual Analogue Scale (VAS)

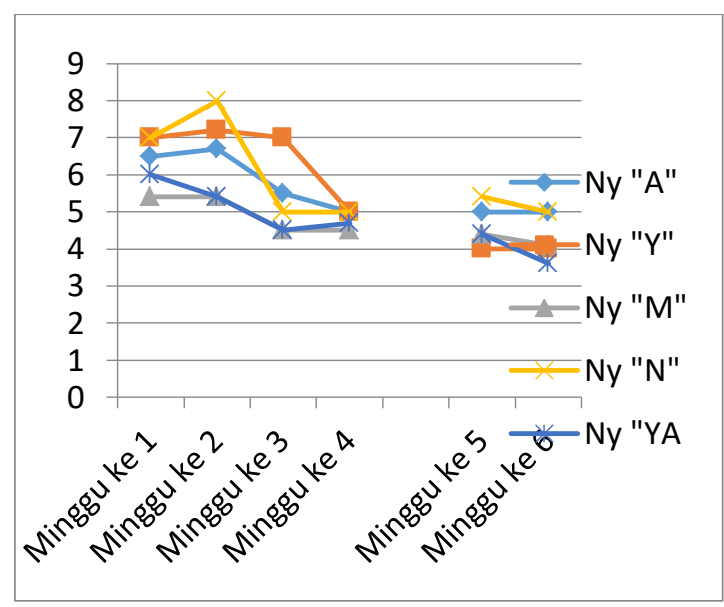

Grafik 2.

Hasil pengukuran derajat nyeri gerak dengan Visual Analoque Scale (VAS)

Hasil dari pengukuran derajad nyeri gerak dengan Visual Analoque Scale (VAS) terhadap 5 (lima) subjek didapatkan penurunan derajad nyeri dengan VAS pada setiap subjek.
Pada baseline awal (intervensi Ultrasound therapy) rata-rata nilai VAS 6.46 , pada fase treatment (penambahan NMT) rata-rata nilai VAS 5.07 dan pada fase baseline 2 atau fase follow up rata-rata nilai VAS 4.49.

3. Hasil Pengukuran Luas Gerak Sendi (LGS) dengan menggunakan Goniometer

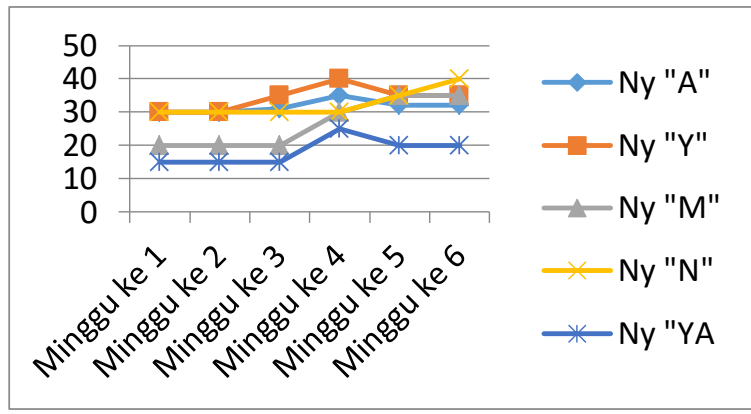

Grafik 2.

Hasil Pengukuran Luas Gerak Sendi (LGS) dengan menggunakan Goniometer

Hasil dari pengukuran Luas Gerak Sendi (LGS) proximal interphalangeal dengan menggunakan Goniometer terhadap 5 subjek didapatkan peningkatan nilai LGS. Pada baseline awal (intervensi Ultrasound therapy) rata-rata nilai LGS proximal interphalangeal $25^{\circ}$, pada fase treatment (penambahan NMT) ratarata nilai LGS $29.1^{0}$ dan pada fase baseline 2 atau fase follow up rata-rata nilai LGS $31.9^{\circ}$.

\section{PEMBAHASAN}

\section{Penurunan Nyeri dengan Skala VAS}

Berdasarkan hasil penelitian yang telah dilakukan, terdapat penurunan rata-rata nilai VAS. Selisih rata-rata penurunan nilai VAS pada fase baseline awal ke fase treatment sebesar 1.39 dan rata-rata penurunan nilai VAS dari fase treatment ke fase baseline 2 atau follow up sebesar 0.58 .

Penurunan nyeri pada fase treatment merupakan efek dari pemberian Ultrasound, Auto stretching dan penurunan nyeri pada fase treatment merupakan efek penambahan 
Neuromuscular taping. Dalam penggunaan ultrasound pada kasus Trigger Finger bertujuan untuk meningkatkan sirkulasi aliran darah yang bermanfaat untuk mempercepat proses penyembuhan pada inflamasi atau peradangan, karena di dalam darah banyak membawa nutrisi yang baik untuk mempercepat proses penyembuhan luka, sehingga rasa nyeri dapat berkurang (Hayes dan Hall, 2016).

Menurut sumber lain, efek dari pemberian Ultrasound (US) therapy dapat memberikan efek mekanik dan efek panas. Gelombang Ultrasound (US) Therapy menimbulkan adanya peregangan didalam jaringan dengan frequensi yang sama dengan frequensi Ultrasound. Oleh karena itu terjadilah variasi tekanan di dalam jaringan atau yang biasa di sebut dengan efek micromassage. Efek micromassage tersebut dapat menghasilkan efek panas dalam jaringan sehingga menyebabkan vasodilatasi pembuluh darah sehingga aliran darah menjadi lancar. Hal ini menyebabkan zat-zat nyeri yang tertimbun dalam darah dapat larut hingga nyeri berkurang (Hadi, 2012).

Pemberian auto stretching memiliki keuntungan tersendiri karena sangat aman dan efektif, terjadinya injuri sangant sedikit, menghasilkan fleksibilitas otot dengan baik dan auto stretching dapat digunakan bagi yang baru mengalami kondisi trigger finger. Agar hasil stretching lebih efektif, pemberian stretching yang benar dengan slowly, genly dan frequenly. untuk itu penulis memilih auto stretching sebagai intervensi pada kondisi trigger finger.

Mekanisme auto stretching terhadap penurunan nyeri dan peningkatan LGS pada trigger finger adalah ketika terjadinya penurunan elastisitas dan kelenturan pada tendon dan selubung tendon, yang diakibatkan oleh adanya inflamasi dan fibrous sehingga timbul abnormal crosslink yang pada akhirnya timbul penebalan dan pembengkakan dan menyebabkan timbulnya aktivitas sitokin pro inflamasi oleh sistem imun sehingga menyebabkan nyeri.

Auto stretching adalah sebagai self stretching karena tipe ini dilakukan sendiri oleh pasien secara aktif, active stretching meningkatkan fleksibilitas secara aktif dan menguatkan otot agonis. Alasan penerapan tehnik ini adalah bahwa kontraksi isotonic yang dilakukan saat auto stretching dari otot yang mengalami pemendekan akan menghasilkan otot memanjang secara maksimal tanpa perlawanan, pemberian auto stretching yang dilakukan secara perlahan dan lembut dapat melepaskan dan merengangkan perlengketan akibat dari abnormal crosslink, pada saat melakukan auto stretching maka panjang otot dapat dikembalikan dengan mengaktifkan muscle spindle, sehingga saat dalam posisi terulur maka muscle spindle akan terbiasa dengan panjang otot yang baru dan memberikan signal ke medulla spinalis dan mengakibatkan meningkatnya stretch reflek dan memberikan panjang otot yang lebih.

Pada saat otot melakukan stretch, maka frekuensi aksi potensial serabut afferent dari muscle spindle dan golgi tendon organ meningkat. Saat otot sedang meregang terjadi penguluran panjang sarkomer penuh menyebabkan pelepasan abnormal crosslink. Pelepasan ini membuat mikro sirkuler menjadi lancar. Sirkulasi yang lancar memudahkan otot untuk berkontraksi dan terjadi elastisitas jaringan. Ikatan pada fasia dan jaringan kolagen terlepas. Dengan mikrosirkuler lancar menyebabkan zat-zat algogen menurun dan nyeri pun berkurang serta kekuatan otot meningkat di harapkan dengan kekuatan otot meningkat maka kemampuan fungsional tangan juga ikut meningkat (Dillah dan Imron, 2013)

Penurunan nyeri pada fase treatment cukup signifkan dengan nilai rata-rata VAS 5.07. Penurunan nyeri tersebut merupakan efek dari penambahan NMT, karena NMT efektif untuk mengurangi nyeri, mengurangi kekakuan otot, mengurangi bengkak / oedema dan memperlancar peredaran darah (Pratama dan Agustiawan, 2018).

Penerapan NMT Pada kasus Trigger Finger menggunakan metode stimulasi decompressive dapat menimbulkan kerutan pada tape sehingga lapisan kulit menjadi terangkat, dengan terangkatnya lapisan kulit tersebut dapat 
mengakibatkan peredaran darah dijaringan tersebut menjadi lancar. Secara prinsip stimulasi decompressive pada NMT ini efektif untuk mengurangi oedema dan melancarkan aliran darah, sehingga rasa nyeri dapat berkurang (Blow, 2015). Menurut Sunarto (2018), NMT memberikan efek meningkatkan range of motion (ROM) pada trigger finger.

Pemberian NMT menggunakan metode stimulasi decompressive, dapat menimbulkan kerutan pada tape sehingga lapisan kulit menjadi terangkat. Dengan terangkatnya lapisan kulit tersebut dapat mengakibatkan peredaran darah dijaringan tersebut menjadi lancar. Secara prinsip stimulasi decompressive pada NMT ini efektif untuk mengurangi nyeri dan melancarkan aliran darah, sehingga rasa nyeri dapat berkurang. NMT dapat menormalkan fungsi otot, meningkatkan aliran limpatik dan vascular, mengurangi nyeri, memperkuat otot-otot yang lemah, dan membantu merileksasi otot-otot yang digunakan secara berlebihan (Berlingieri, 2016).

Berbagai penelitian menyebutkan bahwa NMT memiliki efek Meningkatkan sirkulasi darah, dan mengurangi rasa sakit. Dapat juga untuk memperbaiki keselarasan sendi, mendukung otot selama gerakan, dan meningkatkan stabilitas dan postur (Res, 2017; Alizad dkk, 2009). Dan juga NMT memberikan efek yang sangat baik pada kulit, otot dan sistem peredaran darah, efek teersebut terjadi karna menggunakan teknik dekompresi. NMT menggunakan metode ddekompresi untuk aktivitas sistem kulit, otot, vena dan limfatik serta sendi dengan tujuan untuk mengurangi nyeri dan menormalisasi ketegangan otot (Blow, 2015).

Neuromuscular Taping (NMT) juga dapat mengurangi nyeri, NMT memiliki ciri khas yaitu $0 \%$ tension. NMT biasanya digunakan untuk memperbaiki tonus otot, meningkatkan kontaksi otot, mengurangi kontraksi yang berlebih, menstabilkan fasia, mengurangi nyeri dan meningkatkan pergerakan sendi. Dari bentuk wrinkle yang dihasilkan tape yang telah diaplikasikan ke tubuh pasien sehingga mengangkat kulit dan melancarkan peredaran darah (Blow, 2012).

\section{Peningkatan Luas Gerak Sendi}

Berdasarkan hasil penelitian yang telah dilakukan, didapatkan peningkatan nilai LGS proximal interphalangeal. Persentase peningkatan nilai LGS pada fase baseline awal ke fase treatment sebesar $86 \%$ dan persentase peningkatan nilai LGS dari fase treatment ke fase baseline 2 atau follow up sebesar $91 \%$.

Terjadinya Peningkatan Luas Gerak Sendi (LGS) pada baseline awal dan baseline 2 atau follow up merupakan efek dari pemberian Ultrasound, dan Auto stretching. Dalam pemberian Ultrasound dan Auto Stretching pada kasus Trigger Finger yaitu bertujuan untuk membebaskan perlengketan pada jaringan, itu terjadi karena efek micromassage. Dengan adanya pembebasan pada perlengketan jaringan diharapkan terjadinya peningkatan elastisitas pada jaringan sehingga elastisitas jaringan akan kembali membaik, sehingga kemampuan fungsional diharapkan ikut meningkat (Hayes dan Hall, 2016; Dillah dan Imron, 2013).

Ultrasound (US) Therapy memberikan efek micromassage yang berguna untuk penyembuhan dari cidera tendon dan regenerasi jaringan (Goel \& Joshua, 2015). Pemberian Auto Stretching pada kondisi Trigger Finger yang merupakan metode penguluran otot yang dilakukan sendiri oleh pasien secara aktif untuk meningkatkan fleksibilitas secara aktif dan penguatan otot. Dilakukan secara perlahan dan lembut akan menghasilkan peregangan dan mengembalikan elastisitas sarkomer yang terganggu, dengan meningkatnya elastisitas pada otot maka kekuatan otot akan meningkat dengan meningkatnya kekuatan otot diharapkan kemampuan fungsional tangan juga ikut meningkat (Dilla dan Imron, 2013).

Peningkatan LGS pada fase treatment merupakan efek dari penambahan NMT. Aplikasi NMT juga merupakan koreksi otot dalam bentuk decompressi, dengan teknik ini kulit diatas area yang nyeri dan inflamasi 
diangkat untuk mengurangi hypersensitivitas receptor, hal ini juga dapat memulihkan ketegangan otot, memfasilitasi perluasan otot, dan menormalisasi elastisitas otot, mengurangi kelelahan otot dan meningkatkan kontraksi pada otot sehingga mempengaruhi peningkatan pada luas gerak sendi (Muawanah dkk, 2018 ; Camerota dkk, 2014).

Neuromuscular Taping di tingkat otot bisa memperbaiki tonus otot, meningkatkan kontraksi otot, mengurangi kontraksi otot yang berlebihan, menstabilkan fasia, mengurangi nyeri dan meningkatkan pergerakkan sendi (Pratama dan Agustiawan, 2018).

\section{Simpulan}

1. Berdasarkan nilai rata2 dari baseline awal menggunakan intervensi Ultrasound therapy dan Auto stretching didapatkan penurunan nilai VAS rata-rata 6.46 , pada fase treatment dengan penambahan intervensi NMT didapatkan penurunan nilai VAS dengan nilai rata-rata 5.07 dan fase baseline 2 atau follow up dengan intervensi Ultrasound therapy dan Auto stretching didapatkan penurunan nilai rata-rata VAS 4.49, dapat diasumsikan bahwa penambahan NMT pada Ultrasound therapy dan Auto stretching memberikan pengaruh yang signifikan terhadap penurunan nyeri kasus trigger fringer.

2. Peningkatan LGS proximal interphalangeal untuk baseline awal menggunakan intervensi Ultrasound therapy dan Auto stretching didapatkan penurunan peningkatan nilai LGS rata-rata $25^{0}$, pada fase treatment dengan penambahan intervensi NMT didapatkan peningkatan LGS rata-rata $29^{0}$ dan fase baseline 2 atau follow up dengan intervensi Ultrasound therapy dan Auto stretching didapatkan peningkatan LGS rata-rata $32^{\circ}$. Dengan demikian dapat diasumsikan bahwa pemberian NMT pada intervensi Ultrasound therapy dan Auto stretching memberikan afek peningkatan LGS yang signifikan pada kondisi trigger finger.

\section{Saran}

1. Untuk menegakkan diagnosa fisioterapi secara tepat, diharapkan fisioterapi melakukan pemeriksaan spesifik fisioterapi.

2. Bagi pasien yang mengalami trigger finger untuk meningkatkan kemampuan aktivitas dan fungsional diharapkan dapat melanjutkan latihan Auto Stretching di rumah.

3. Bagi peneliti selanjutnya diharapkan agar dapat melakukan penelitian dengan jumlah sampel yang lebih besar, dan dengan intervensi yang berbeda.

\section{DAFTAR PUSTAKA}

Blow, D. (2015). Neuromuscular Taping. From Theory to Practice. Edi-ermas. Milan. Italy.

Berlingieri, dkk. (2016). Possible Application Of Neuromuscular Taping In Pain Reduction In Multiple Sclerosis Subject : a preliminary report. Vol. 10.14616. Hlm. 303-307. Senses Sclences.

Camerota, et all (2015). Does Neuromuscular Taping Influence Hand Kinesiology? A Pilot Study on Down Syndrome. Societa Editrice Universo (SEU). https://www.researchgate.net/profile/Fili ppo Camerota/publication/282039951 Does_neuromuscular_taping_influence hand kinesiology A pilot study on D own's_Syndrome/links/562a8d8d08ae22 b17031c0d4/Does-neuromusculartaping-influence-hand-kinesiology-Apilot-study-on-Downs-Syndrome.pdf

Dillah, U., \& Imron, A. (2013). Auto Stretching dan Transverse Friction lebih baik dari pada Paraffin Bath dan Transfer 
Friction Terhadap Kemampuan Fungsional Tangan Pada Kasus Trigger Finger. Jurnal Fisioterapi. 13 (1),33-45.

Fauzi, A., (2015). Trigger Finger. Juke Unila. 5(9):134-140.

Goel Ritu, Joshua M. Abzug (2014). De Quervain's Tenosynovitis ; a review of Rehabilitative Options. American Association of Hand Surgery. https://www.ncbi.nlm.nih.gov/pmc/articl es/PMC4349843/

Hadi Bisri (2012). Perbedaan Efek Antara Transverse Friction dan Kinesiotaping pada Intervensi Ultrasound Terhadap Nyeri dan Disabilitas Ibu Jari pada Kasus De Quervein Syndrome. Fakultas Fisioterapi Universitas Esa Unggul Jakarta.

https://digilib.esaunggul.ac.id/public/UE U-Undergraduate-8255-JURNAL.pdf

Hayes, K. W., \& Hall, K. D. (2016). Agen Modalitas Untuk Praktek Fisioterapi. Edisi, 6 Jakarta: Buku Kedokteran EGC.

Helmi, Z, N. (2013). Buku Ajar Gangguan Muskuloskeletal. Jakarta : Salemba Medika.

Muawanah Siti, Azminggu Muhammad Herli (2018). Perbedaan Pemberian Neuromuscular Taping dan Ultrasound (US) Lebih Baik daripada Neuromuscular Taping (NMT) dan Infra Red (IR) dalam Mengurangi Nyeri pada Kasus De Quervein Syndrome. Prosiding Seminar Nasional Aplikasi
Sains dan Teknologi (SENATEK). Universitas Abdurrab Pekanbaru.

Mujianto. (2013). Cara Cepat Mengatasi 10 Besar Kasus Muskuloskeletal Dalam Praktik Klinik Fisioterapi. Jakarta: TRANS INFO MEDIA.

Noor, Z. (2016). Buku Ajar Gangguan Muskuloskeletal. Jakarta : Salemba Medika.

Kisner, C., \& Colby, L. A. (1990). Therapeutik Exercise Foundations and Tecniques. Printed in Canada.

Pratama, Aditya, D \& Agustiyawan. Application Of Neuromuscular Taping On Thumb Arthtritis Condition:Case Study. Jakarta Selatan : NMT Indonesian Symposium 2018

Trisnowiyanto, B. (2012). Instrumen Pemeriksaan Fisioterapi dan Penelitian Kesehatan. Yokyakarta: Nuha Medika.

PERMENKES. (2013). Peraturan Mentri Kesehatan tentang penyelenggaraan pekerjaan dan praktik fisioterapi. www.djpp.kemenkumham.go.id.

Sunarto. (2018). Proceeding The 2 Indonesian Neuromuscular Taping Symposium " A Multi Profesional Approach Using Neuromuscular Taping (NMT) Application Cases". Solo Indonesia, 2221.

Trisnowiyanto, B. (2012). Instrumen Pemeriksaan Fisioterapi dan Penelitian Kesehatan. Yokyakarta: Nuha Medika 